Accepted: 30/04/2021, Reviewed: 30/07/2021, Published: 31/10/2021

\title{
CONCENTRATION OF LONTAR SUGAR (Borassus flabellifer Linn) AND ITS EFFECT ON PHYSICOCHEMICAL AND ORGANOLEPTIC PROPERTIES OF VILLAGE CHICKEN JERKY
}

\author{
Yelia May Danga Ndia*, Yessy Tamu Ina, Alexander Kaka \\ Animal Husbandry Study Program, Faculty of Science and Technology, Wira Wacana \\ Christian University, Sumba. \\ JI. R. Suprapto No. 35, Waingapu, Prailiu, East Sumba Regency, NTT \\ * Correspondence Author, email: rambuyelia@gmail.com
}

\begin{abstract}
This study aims to determine the different concentrations of palm sugar on the physicochemical and organoleptic properties of chicken jerky. This study used RAL with 4 treatments and 5 replications, namely soaking chicken meat with a concentration of palm sugar $10 \%-40 \%$. Observation variables were water content, $\mathrm{pH}$, antioxidant and organoleptic. The data obtained include data on water content, $\mathrm{pH}$ and organoleptic then analyzed by ANOVA at $95 \%$ level. While the total antioxidants were tested descriptively. The results of the analysis showed that the concentration of palm sugar $10 \%-40 \%$ contained water content (8.52-10.52\%), the concentration of palm sugar $10-40 \%(6.33-5.64 \%)$ The higher the concentration of palm sugar in chicken meat jerky In chicken, the lower the $\mathrm{pH}$, the antioxidants produced in each treatment of palm sugar were $10 \%-40 \%(79.28 \%-83.23 \%)$ and $40 \%$ palm sugar could increase the panelists' acceptance of organoleptic.
\end{abstract}

Keywords: Free-range chicken, Jerky, Organoleptic, Palm sugar, Physicochemical properties

\section{INTRODUCTION}

Meat is one of the important sources of animal food to meet the needs of society. According to (Ina et al., 2019), meat is a food material with high nutritional value and a source of animal protein commodities. (Mahemba et al., 2014) State that native chicken meat has high nutritional value, namely water content of $75.52 \%$, protein $22.26 \%$, fat $1.92 \%$, calcium, $13 \mathrm{mg}, 190 \mathrm{mg}$ phosphorus and $1.5 \mathrm{mg}$ iron. The high nutritional value in the meat is a good medium for microbial growth so that it can cause physical and chemical damage to the meat, so that proper handling is needed so that chicken meat can be stored for a long time. (Mahemba et al., 2014) stated that, meat which has high nutritional value, is cheaply damaged due to physical impact and microbial activity, so that proper handling is needed so that the chicken meat can be stored.

The addition of sugar aims to preserve and reduce water activity in chicken meat jerky so as to prevent microbial growth (Evanuarini et al., 2011). One way to maintain the shelf life of meat is to process chicken meat jerky using palm sugar. Palm sugar is expected to extend the storage period, increase the distinctive taste, and can maintain its nutritional value (Afrila et al., 2011). Palm sugar contains antioxidant compounds that function to protect the body from free radicals. Preservation of chicken meat by using palm sugar functions as a humectant, prevents physical damage, restrains microbial growth, improves meat color and makes food more nutritious and contains antioxidants which are important in maintaining a healthy body because it works as an antidote to free radicals (Palealu et al., 2011).

Making chicken jerky is one of the food diversification efforts as well as helping the Indonesian government program in providing products derived from animal food. Diversification can also increase consumer acceptance of the distinctive taste of food products 
of animal origin (Rakhmawati et al., 2016). Furthermore, added by (Mahemba et al., 2014) states that jerky is one of the dry products that has been widely processed in Indonesia and has a shelf life of more than 6 months with an average moisture content of $15 \%-20 \%$.

Based on the description above, it is necessary to conduct research with the title "Concentration of Palm Sugar (Borassus Flabellifera Lin) and Its Effect on the Physicochemical and Organoleptic Properties of Kampung Chicken Jerky". The purpose of this study was to determine the effect of palm sugar concentration on the quality of native chicken jerky on water content, $\mathrm{pH}$, total antioxidants and organoleptics (color, taste, texture, and level of preference) so that the resulting product becomes a long-lasting food potential, preserves its nutritional value and healthy.

\section{METHODOLOGY}

This research was carried out in October-December 2020 at the Integrated Christian University, Sumba and Antioxidant testing was carried out at the Integrated Laboratory of the Diponegoro University, Semarang.

\section{Materials}

The materials used in this study were 2 male free-range chickens and 4 female pelung chickens aged 5-6 months obtained from Nggongi Village, Karera District, East Sumba Regency and the meat taken was the chest and thighs, palm sugar $500 \mathrm{gr}, 1 \mathrm{gr}$ salt, $10 \mathrm{gr}$ garlic, $10 \mathrm{gr}$ onion, $4 \mathrm{gr}$ galangal, $3 \mathrm{gr}$ ginger, $3 \mathrm{gr}$ coriander, $1 \mathrm{gr}$ cooking and $1 \mathrm{gr}$ marica.

\section{Equipment}

The equipment used in the processing of chicken jerky is to use the analytical scale of the High Precision Balance brand to weigh the samples of chicken meat and palm sugar and according to the treatment. The chicken meat is sliced using a stainless knife with a thickness of $3 \mathrm{~cm}$, then place the chicken meat in the beaker glass and soak the chicken meat with melted palm sugar and the top of the beaker glass is covered with cling wrap and the chicken meat is soaked for 30 minutes. The soaked chicken meat is placed on a tray lined with woven wire, then the chicken meat is dried in the sun for 8 hours. The dried chicken meat jerky product was placed in a zipper bag and continued with variable analysis.

\section{Research Design}

This study used (CRD) with 4 treatments and 5 replications, namely soaking chicken meat with $10 \%$ palm sugar concentration (P1), soaking chicken meat with $20 \%$ palm sugar concentration (P2), soaking chicken meat with $30 \%$ palm sugar concentration (P3), soaking chicken meat with a concentration of $40 \%$ palm sugar (P4) so there are 20 sample units. The data obtained include data on water content, $\mathrm{pH}$ and organoleptic then analyzed by ANOVA at $95 \%$ level. While the total antioxidants were tested descriptively.

\section{Step in Research Process \\ 1. Chicken Meat Sample Preparation}

The preparation stage includes an antemortem examination, which is to see the physical condition of the livestock which is healthy with the characteristics: the chicken's eyes are not lethargic, the comb is red, actively moving, the feathers are not worn, the breath is not short of breath. Postmortem examination is characterized by the absence of offal abnormalities, carcasses, and no abnormalities in the chicken meat.

\section{Making and giving treatment to jerky}

The jerky processing procedure is as follows:

a) The breast and thighs are taken from 6 chickens

b) Chicken meat is cleaned of fat and the skin is sticking, after that it is washed thoroughly and then cut into thin strips following the muscle tissue. 
c) Chicken meat that has been sliced is marinated in a solution of spices and palm sugar according to the treatment concentration for 30 minutes.

d) The soaked chicken meat is drained for 30 minutes. Then dry it through the sun for \pm 8 hours, and every 4 hours the jerky is behind.

e) After drying, the sample is tested including water content, $\mathrm{pH}$, antioxidant and organoleptic tests (color, taste, texture and preferences).

\section{Methods}

This study used a completely randomized design method (CRD) with 4 treatments and 5 replications, namely soaking chicken meat with a concentration of palm sugar $10 \%(\mathrm{P} 1)$, soaking chicken meat with a concentration of palm sugar $20 \%$ (P2), soaking chicken meat with a concentration of palm sugar $30 \%$ ( P3), soaking the chicken meat with a concentration of palm sugar $40 \%$ (P4) so that there are 20 sample units.

\section{Analytical Procedure}

\section{Variables Observed in Research}

\section{Water Content}

Analysis of moisture content was carried out using the oven method (AOAC) 1995; (Ina et al., 2019)). Prepare a sample of 20 pieces weighing 5 grams and weigh it so that the initial weight is known before oven, after weighing, the sample is put into an oven at 105$110^{\circ} \mathrm{C}$ for 6 hours (Mahemba et al., 2014) after the sample is oven weighed to determine the final weight of the sample that has been ovenized according to each treatment and repetition.

$$
\begin{aligned}
& \text { Water content } \% \frac{B 1-B 2}{B 1} X \quad 100 \% \\
& \text { B1 = initial weight before oven } \\
& \text { B2 = The final weight in the oven }
\end{aligned}
$$

\section{2. $\mathrm{pH}$}

The $\mathrm{pH}$ test uses an Inava type $\mathrm{pH}$ meter. The trick is to calibrate the $\mathrm{pH}$ meter with distilled water ( $\mathrm{pH} 7$ ), then weigh the sample as much as 5 grams and smooth the chicken meat using a mortar and dissolve $50 \mathrm{ml}$ of distilled water, then put the $\mathrm{pH}$ meter into the chicken meat solution and see the $\mathrm{pH}$ value (Sumatra, 2007).

\section{Antioxidants}

Antioxidant activity testing was carried out using the DPPH method and using a DPPH solution with a concentration of $6 \times 10^{-5} \mathrm{M}$. This concentration was obtained by dissolving 1.182 $\mathrm{mg}$ of DPPH into $50 \mathrm{ml}$ of methanol. The test solution was obtained by mixing $200 \mu \mathrm{l}$ into $1 \mathrm{ml}$ of methanol which was then centrifuged until a precipitate was formed. After that, put $1 \mathrm{ml}$ of the test solution into a tube protected from light, then add $1 \mathrm{ml}$ of DPPH. Furthermore, the solution was incubated at $37^{\circ} \mathrm{C}$ for 30 minutes in a dark room. During the process by antioxidants, the DPPH radical solution will change color from purple to pale yellow. This decrease in absorbance was measured with a spectrophotometer at a wavelength of $517 \mathrm{~nm}$ (As). The blank solution used consisted of $1 \mathrm{ml}$ of methanol in $1 \mathrm{ml}$ of DPPH measured at the same wavelength $(\mathrm{Ab})$. Trolox was used as a positive control. The DPPH test was treated with two repetitions. The value of inhibition is measured by calculating Ab minus As then divided by As then multiplied by $100 \%$ (Suliasih et al., 2018).

\section{Organoleptic (Color, Taste, Texture and Likes)}

Organoleptic testing is carried out through sensory testing by determining 25 panelists who can be considered to have represented the consumer population. Organoleptic testing of 
chicken meat jerky samples weighing 5 grams per treatment (Soputon, 2004). Organoleptic testing includes:

a) Color

The color of the chicken meat is one of the indicators that appear first before determining the parameters for the quality of the chicken meat. The color scores that are assessedare: 4 = very brown, 3 = brown, 2 = less brown and $1=$ not brown.

b) Texture

Texture can affect consumers of a product. The texture score assessed is: $4=$ very soft, $3=$ soft, 2 = less soft and $1=$ not soft

c) Taste

The taste scores used are: $4=$ Very Good, $3=$ Good, $2=$ Not Good and $1=$ Not Good

d) passions

Overall acceptance is an organoleptic acceptance of the product in general, that is, the researcher sees the overall properties of the chicken jerky product (taste, texture, aroma, color and level of preference). The favorite scores used are: $4=$ Very like very much, 3 = Like it, 2 = a little like it and $1=$ dislike it.

\section{RESULTS AND DISCUSSION}

\section{Water content}

The water content of food products is very influential in the storage time of the product. The effect of palm sugar concentration on the water content of chicken jerky can be seen in Table 1 below.

Table 1. Average Water Content of Chicken Jerky with Various Levels of Palm Sugar Concentration

\begin{tabular}{ccc}
\hline No & Treatment & Water content (\%) \\
\hline 1. & $10 \%$ & $8.52^{\mathrm{a}}$ \\
2. & $20 \%$ & $9.36^{\mathrm{b}}$ \\
3. & $30 \%$ & $9.65^{\mathrm{b}}$ \\
4. & $40 \%$ & $10.52^{\mathrm{c}}$ \\
\hline
\end{tabular}

Note: Different abc superscripts on the same line show significant differences $(P<0.05)$.

Based on Table 1. This study shows that the highest water content of chicken jerky is found in the utilization of palm sugar concentration $40 \%(10.52 \%)$, followed by $30 \%$ treatment $(9.65 \%), 20 \%(9.36 \%)$ and $10 \%(8.52 \%)$. In the processing of jerky, what is expected is a low water content. The lowest water content was found in the $10 \%$ treatment $(8.52 \%)$ because it was caused by palm sugar where the lower the palm sugar was given, the lower the water content in the chicken meat jerky, due to the ability of palm sugar to bind water due to hydrogen bonds and the concentration of palm sugar. The lowest level is more soluble in food, causing a lower vapor pressure, causing water to evaporate more easily than the dried material (Pursudarsono et al., 2015). The highest water content was found in the $40 \%$ treatment where the higher the palm sugar concentration, the higher the water content of the chicken meat jerky, the chicken meat jerky which was treated with $40 \%$ sugar concentration experienced a higher water content than the $10 \%$ treatment, this was due to the increased concentration of palm sugar. which is added in the processing of chicken meat jerky and during the soaking and drying process, there is a transfer of fluid by osmosis from the outside into the chicken meat. According to Franson (1992), states that the fluid movement occurs so that on both sides of the membrane there is a balanced pressure. The difference in pressure and concentration between the concentration of palm sugar added to the chicken meat affects the amount of liquid that enters and the speed at which the liquid moves. The water content in chicken meat jerky according to (SNI 01-2908-2013) is 12\%. Based on the results of the study, it can be concluded that the lower the concentration of palm sugar in chicken jerky, the lower the water content of jerky and conversely the higher the concentration of palm sugar, the 
higher the water content in chicken meat jerky, which is found in the treatment $40 \%(10.52 \%)$ and supported by the results of his research, (Evanuarini et al., 2011) stated that jerky with the addition of $10 \%$ sugar contained water content $(11.80 \%)$, added sugar $20 \%$ water content $(12.67 \%)$, added sugar $30 \%$ water content $(13.73 \%)$, then the addition of palm sugar with a high concentration in dissolved solids is not available for the growth of microorganisms.

\section{2. $\mathrm{pH}$}

The $\mathrm{pH}$ value is the degree of acidity that is used to express the level of acidity or wetness that a solubility has. The effect of palm sugar concentration on jerky can be seen in Table 2.

Table 2. Average pH Value of Village Chicken Jerky with Various Levels of Palm Sugar Concentration

\begin{tabular}{ccc}
\hline No. & Treatment & pH (\%) \\
\hline 1. & $10 \%$ & $6.33^{\mathrm{a}}$ \\
2. & $20 \%$ & $6.17^{\mathrm{a}}$ \\
3. & $30 \%$ & $5.92^{\mathrm{b}}$ \\
4. & $40 \%$ & $5.64^{\mathrm{c}}$ \\
\hline
\end{tabular}

Note: Different abc superscripts on the same line show significant differences $(P<0.05)$.

Based on Table 2. The results of this study showed that the $\mathrm{pH}$ of the chicken jerky produced was in the $10 \%, 20 \%$ treatment significantly different from the $30 \%$ and $40 \%$ treatments. This study showed that the highest $\mathrm{pH}(6.33 \%)$ was in chicken meat that received $10 \%$ palm sugar concentration treatment, while the lowest $\mathrm{pH}$ was chicken meat jerky which received $40 \%$ sugar concentration treatment with a total pH of 5.64. Irmayuni et al., (2018) which states that the decrease in $\mathrm{pH}$ occurs because palm sugar contains complete nutrients such as sugar, protein, fat and minerals, this causes palm sugar to become acidic because the results of metabolism are ethanol and $\mathrm{CO}_{2}$, the content of Both of these substances are acidic so that there is a decrease in the value of the degree of acidity $(\mathrm{pH})$. further research by Pursudarsono et al., (2015) stated that, the $\mathrm{pH}$ value in foodstuffs that were given sugar $20 \%(5.75 \pm 0.08)$, sugar $30 \%(5.77 \pm 0.19)$, sugar $40 \%(5.90 \pm 0.06)$ and high sugar content along with low acid content can increase the shelf life of foodstuffs. Handayani et al., (2015) stated that the $\mathrm{pH}$ value of chicken meat jerky in the home industry is 5.85 on average. It can be concluded that the results of the study of chicken jerky that received treatment with a sugar concentration of $40 \%$ were the best because they were close to the $\mathrm{pH}$ value of chicken meat jerky products on a household scale. Furthermore, added by Zulfahmi, (2010) stated that normal conditions of meat $\mathrm{pH}$ and less favorable for bacterial growth at $\mathrm{pH}$ 5.3-5.7 Bacteria grow at $\mathrm{pH} 7.0$, fungi at $\mathrm{pH}$ 2.0-8.0 while yeast can grow at $\mathrm{pH}$ 4.0-4.

\section{Antioxidants}

The effect of palm sugar concentration on total antioxidants affects the chicken jerky produced. The total antioxidants in chicken jerky can be seen in Table 3.

Table 3. Total Antioxidants of Chicken Jerky with Various Concentrations of Palm Sugar.

\begin{tabular}{ccc}
\hline No. & Treatment & Antioxidants (\%) \\
\hline 1. & $10 \%$ & 81.08 \\
2. & $20 \%$ & 79.28 \\
3. & $30 \%$ & 83.23 \\
4. & $40 \%$ & 80.00 \\
\hline
\end{tabular}

The effect of palm sugar concentration on the total antioxidants of jerky can be seen in Table 3. The results showed that the concentration of palm sugar can produce total 
antioxidants of free-range chicken jerky. It can be seen that the total antioxidant in the $10-40 \%$ treatment was $81.08-83.23 \%$, but in the $30 \%$ treatment the total antioxidant value was higher than the $40 \%$ treatment. This shows that the concentration of palm sugar up to $30 \%$ can increase the total antioxidants in chicken meat jerky products with a total antioxidant produced of $83.23 \%$. Fastawa et al., (2016); (Momuat et al., (2016) stated that, the high and low antioxidant content in the treatment depends on the storage time and the concentration of the ingredients used. This is supported by Adjis et al., (2019) stating that, the total antioxidant in chicken meat jerky is by utilizing brown sugar 40\% (355.23-201.98\%).

\section{Organoleptic Test (Color, Taste, Texture and Likes).}

Organoleptic testing is a method of testing using the human senses as the main tool for assessing quality (SNI 01-2336-2006), organoleptic testing includes indicators of color, texture, taste and level of preference for the product. The average organoleptic assessment of chicken jerky can be seen in Table 4.

Table 4. Organoleptic Average Value of Chicken Jerky with Various Levels of Palm Sugar Concentration.

\begin{tabular}{ccccc}
\hline \multicolumn{5}{c}{ Variable } \\
\hline Treatment & Color & Taste & $\begin{array}{c}\text { Texture } \\
\text { Deuteronomy }\end{array}$ & Passions \\
\hline $10 \%$ & $2.60 \pm 0.70^{\mathrm{a}}$ & $2.36 \pm 0.81^{\mathrm{a}}$ & $2.04 \pm 0.73^{\mathrm{a}}$ & $2.52 \pm 1.04^{\mathrm{a}}$ \\
$20 \%$ & $2.56 \pm 0.82^{\mathrm{a}}$ & $2.72 \pm 0.84^{\mathrm{ab}}$ & $2.40 \pm 0.76^{\mathrm{a}}$ & $2.84 \pm 0.68^{\mathrm{a}}$ \\
$30 \%$ & $2.76 \pm 0.83^{\mathrm{a}}$ & $3.00 \pm 0.76 \mathrm{~b}^{\mathrm{c}}$ & $2.16 \pm 0.94^{\mathrm{a}}$ & $2.84 \pm 0.78^{\mathrm{a}}$ \\
$40 \%$ & $2.80 \pm 0.86^{\mathrm{a}}$ & $3.20 \pm 081^{\mathrm{c}}$ & $2.32 \pm 0.945^{\mathrm{a}}$ & $2.96 \pm 0.93^{\mathrm{a}}$ \\
\hline
\end{tabular}

Note: Different abc superscripts on the same line show significant differences $(\mathrm{P}<0.05)$.

\section{Color}

Color is one of the indicators that appears first before determining the parameters of chicken meat quality. The effect of palm sugar concentration can be seen in Table 4.

The results of the ANOVA test showed that the color of chicken jerky produced in the treatment of $10 \%(2.60 \pm 0.70), 20 \%(2.56 \pm 0.82), 30 \%(2.76 \pm 0.83)$ and $40 \%(2.80 \pm 0.86)$ was not significantly different $(P>0.05)$ however, at $40 \%$ palm sugar concentration it produced a very brown jerky color and the highest value of chicken meat jerky color was in the $40 \%$ treatment. The appearance of a brown color in the jerky product is due to the Maillard reaction and this reaction produces a dark brown color reaction to heat, resulting in the color of the jerky becoming blackish brown and during frying there is a heat reaction to the sugar which causes the jerky color to darken.

This is supported by the results of research by Febrianingsih et al., (2016) which states that the average color value of chicken meat jerky with palm sugar is $10 \%(3.40), 20 \%(2.20)$, $30 \%(2.40), 40 \%(2.40)$.

\section{Taste}

Taste can affect consumers towards a product of chicken jerky. The effect of differences in palm sugar concentration can be seen in Table 6.

The results showed that there was a significant effect $(P<0.05)$. The $10 \%$ and $20 \%$ treatments were significantly different from the $30 \%$ and $40 \%$ treatments. This study shows that the study gave the highest score for the $40 \%$ treatment, this is because the sugar compound sucrose, fructose in palm sugar diffuses into the chicken meat so that it affects the chicken meat jerky produced to taste sweeter and distinctive by Bani et al., (2020). The results of research by Febrianingsih et al., (2016) stated that the higher the level of addition of palm sugar, the change in the taste of chicken meat jerky to be more distinctive and preferred by consumers. The results of further research show that ground chicken meat jerky with the addition of $10 \%-30 \%$ palm sugar produced an average chicken meat jerky texture of $1.93 \%$ - 
3.13\%. Rakhmawati et al., (2016) stated that, the taste of a chicken meat jerky product comes from the use of spices so that it has a distinctive taste in chicken meat jerky.

\section{Texture}

The texture of a product is a major factor that is considered in the assessment that affects consumer tastes. The effect of palm sugar concentration on the treatment can be seen in Table 4.

The results of the ANOVA test showed that the texture of chicken jerky produced in the treatment was $10 \%(2.04 \pm 0.73), 20 \%(2.40 \pm 0.76), 30 \% 2.16 \pm 0.94), 40 \%(2.32 \pm 0.94)$ not significantly different $(P>0.05)$ however, at $40 \%$ palm sugar concentration the texture can give tenderness to chicken jerky. The higher the palm sugar concentration, the higher the tenderness of the jerky. This is supported by Febrianingsih et al., (2016) which states that the average value of chicken meat jerky tenderness is palm sugar $10 \%(3.13), 20 \%,(1.93), 30 \%$ (2.27), 40\% (2.20) and the higher Palm sugar added to the chicken meat jerky will make the jerky more tender, on the contrary, the lower the palm sugar will affect the lower the tenderness of the chicken meat jerky. Furthermore, Rakhmawati et al., (2016) stated that the increase in tenderness is a reaction to water content.

\section{Passions}

Likes is the overall acceptance of the panelists towards a chicken jerky product which includes (color, taste, texture and preference) and the final result of the panelists' assessment of the chicken jerky product. Panelist's evaluation of the preference for chicken meat jerky products can be seen in Table 4.

ANOVA test results showed no significant difference $(P>0.05) 10 \%(2.52 \pm 1.04), 20 \%$ (2.84 \pm 0.68$), 30 \%(2.84 \pm 0.78)$ and $40 \%(2.96 \pm 0.93)$ on the panelists' preference for chicken meat jerky products, however, at $40 \%$ palm sugar concentration, the panelists' preference was greater in the $40 \%$ treatment. This is supported by Rakhmawati et al., (2016) which states that the overall acceptance of organoleptic products (color, taste, texture and level of preference) and as the final result of the panelist's assessment of the response of the panelists to commercial chicken jerky was equally increased.

\section{CONCLUSION}

1. Based on the results of the study, it can be concluded that the concentration of palm sugar $10 \%-40 \%$ can affect the physical properties $(\mathrm{pH})$, water content and total antioxidants. The concentration of palm sugar $10 \%$ can reduce the lowest water content of $8.52 \%$, the $\mathrm{pH}$ value of 5.64 meets product safety standards and the concentration of palm sugar is up to $40 \%$, the highest total antioxidant is $83.23 \%$. At $30 \%$ palm sugar concentration

2. Organoleptic chicken jerky with different concentrations of palm sugar, color, texture and preference were not significantly different but from the highest value, the utilization of palm sugar was $40 \%$ and organoleptic (texture) was softer once there was a concentration of $40 \%$ palm sugar.

\section{SUGGESTION}

It is necessary to carry out further research on the utilization of palm sugar with a higher concentration and to analyze the length of storage and its effect on the durability of jerky, protein content, fat content, sucrose and sugar content.

\section{ACKNOWLEDGMENTS}

The author would like to thank the Wira Wacana Sumba Integrated Laboratory of the Christian University for providing the opportunity for the author to conduct research, analysis and sample testing. Thanks also to the Integrated Laboratory of Diponegoro University Semarang which has helped in analyzing research samples. 


\section{REFERENCES}

Afrila, A., \& Santoso, B. (2011). Water Holding Capacity (WHC), Kadar Protein, Dan Kadar Air Dendeng Sapi Pada Berbagai Konsentrasi Ekstrak Jahe (Zingiber officinale Roscoe) Dan Lama Perendaman Yang Berbeda. 6(2), 41-46. https://doi.org/doi.org/10.1109/5.771073)

Associatis of Official Analycal Chemist (AOAC). (1995). Official Methors of Analysis $16^{t}$ Edition Maryland (US).

Bani, M. M., Putranto, W. S., \& Suradi, K. (2020). Total Mikroba Dan Akseptabilitas Daging Sapi Marinasi Pada Berbagai Lama Perendaman Gula Lontar Cair (Borassus flabellifer). 8(1), 29-36. https://doi.org/doi.org/10.20956/jitp.v8i1.7946

Evanuarini, H., \& Huda. (n.d.). Quality of Dendeng Giling on Different Sugar Addition. Jurnal IImu-IImu Peternakan, 21(2), 7-10.

Fastawa, R., Nahariah, \& Maruddin, F. (2016). Optimasi Antioksidan Dengan Lama Fermentasi Yang Berbeda Pada Telur Infertil Sisa Hasil Penetasan. JITP, 5(1), 58-65. https://doi.org/doi.org/10.20956/jitp.v5i1.1530

Febrianingsih, F., Hafid, H., \& Amiluddin Indi. (2016). Kualitas Organoleptik Dendeng Sapi Yang DiBeri Gula Merah Dengan Level Yang Berbeda. JITRO, 3(2), 11-15. https://doi.org/doi.org/10.33772/jitro.v3i2.1678

Halid, S. A., \& Rahim, A. (2018). Sifat fisik, kimia dan Aktivitas Antioksidan Abon Daging Ayam di Kota Palu. J. Agroland, 25(2), 154-163.

Handayani, B. R., Margana, C. C. E., Kertanegara, Hidayati, A., \& Werdiningsih, W. (2015). Kajian Waktu Perendaman "Marination" Terhadap Mutu Dendeng Sapi Tradisional Siap Makan. J. Teknol. Dan Industri Pangan, 26(1), 17-25. https://doi.org/10.6066/jtip.2015.26.1.17

Ina, Y. T., Widiyanto, \& Valentinus Priyo Bintoro. (2019). Sifat Fisikokimia Dendeng Sapi yang Direndam dalam Gula-Kelapa dan Madu. Jurnal Aplikasi Teknologi Pangan, 8(1), 13-16. https://doi.org/doi.org/10.17728/jatp.3760 13

Irmayuni, E., Nurmila, \& Andi Sukainah. (2018). Efektivitas Air nira Lontar (Borassusflabellifer) Sebagai Bahan Pengembang Adonan Kue Apem. Jurnal Pendidikan Teknologi Pertanian, 4, 170-183.

Kosim, A. (2015). Sifat fisik dan Aktivitas Antioksidan Dendeng Daging Sapi Dengan Penambahan Stroberi (Fragaria Ananassa) Sebagai Bahan Curing.

Lestari, H. W., Sari, N. I., \& Leksono, T. (2019). Pengaruh Metode Pemasakan Basah Berbeda Terhadap Mutu Dendeng Lumat Kijing (Anadonta Woodiana Lea).

Mahemba, M. L., Sipahelut, G. M., \& Malelak, G. E. M. (2014). Kandungan Air, Kandungan Protein dan sifat Organoleptik Dendeng Ayam Kampung Jantan Tua Yang Di Beri Berbagai Jenis Gula. Jurnal Nukleus Peternakan, 1(2), 135-142.

Momuat, L. I., \& Suryanto, E. (2016). Pengaruh Lama Perendaman Terhadap Aktivitas Antioksidan Dari Empelur Sagu Baruk ( Arenga Microcharpha ). Chem. Prog, 9(1), 2128. https://doi.org/:doi.org/10.35799/cp.9.1.2016.13909

Palealu, K., Pontoh, J., \& Suryanto, E. (2011). Pengaruh Pemanasan Terhadap Aktivitas Antioksidan Dalam Pembuatan Gula Aren. Chem. Prog, 4(2), 60-64. https://doi.org/doi.org/10.35799/cp.4.2.2011.4975

Purnamasari, E., Munawarah, D. S., \& Zam, D. S. I. (2013). Mutu Kimia Dendeng Semi Basah Daging Ayam Yang Direndam Jus Daun Sirih (Piper Betle L.) Dengan Konsentrasi Dan Lama Perendaman Berbeda. Jurnal Peternakan, 10(1), 9-17. https://doi.org/doi.org/10.24014/jupet.v10i1.153

Pursudarsono, F., Rosyida, D., \& Aris Sri Widati. (2015). Pengaruh Perlakuan Imbangan Garam Dan Gula Terhadap Kualitas Dendeng Paru-Paru Sapi. Jurnal IImu Dan Teknologi Hasil Ternak, 10(1), 35-45. https://doi.org/doi.org/10.21776/ub.jitek.2015.010.01.5

Rakhmawati, R., Sulistyoningsih, M., \& Puteri, A. N. (2016). Pengaruh Aenis ayam Terhadap Uji Organoleptik Pada Dendeng Ayam. Program Studi Pendidikan Biologi FPMIPATI Universitas PGRI Semarang, 125-131. 
Soputon, J. E. . (2004). Dendeng Sapi Sebagai Alternatif Pengawetan Daging.

Suliasih, Legowo, A. M., \& Tampoebolon, B. I. M. (2018). Aktivitas Antioksidan , BAL , Viskositas dan Nilai $L{ }^{*} a{ }^{*} b$ * Dalam Yogurt Yang Diperkaya Dengan Probiotik Bifidobacterium Longum Dan Buah Naga Merah ( Hylocereus Polyrhizus ). Jurnal Aplikasi Teknologi Pangan, 7(4), 151-156. https://doi.org/doi.org/10.17728/jatp.3061 Legow

Sumatra, A. (2007). Sifat Fisik Organoleptik fermentasi Daging Sapi (pp. 2-30).

Zulfahmi, M. (2010). Daya Ikat Air, Kadar Air, pH Dan Organoleptik Daging Ayam Petelur Akfir Yang Direndam Dalam ekstrak Kulit Nenas (Ananas comosus L. Merr) Dengan Konsentrasi Yang Berbeda. 17-37. http://repository.uin-suska.ac.id/id/eprint/10673 